\title{
Da literatura gauchesca para as histórias em quadrinhos: uma leitura do poema telúrico Inodoro Pereyra, el renegau
}

\author{
Gaucho literature to comic books: a reading of the poem telluric \\ Odorless Pereyra, el renegau
}

Priscila Pereira ${ }^{1}$

RESUMO

Neste artigo pretende-se discutir a relação entre história em quadrinhos (HQ) e literatura a partir da análise da historieta argentina Inodoro Pereyra, el renegau. O quadrinho foi criado pelo humorista gráfico rosarino Roberto Fontanarrosa para a revista Hortensia como uma paródia da literatura gauchesca, do radioteatro e do folclore argentinos. Além disso, a aparição de Inodoro Pereyra na imprensa cordobesa em 1972 coincide com a comemoração do centenário do poema Martín Fierro, de José Hernández. Não é por acaso, portanto, que Fontanarrosa tenha se inspirado neste clássico da literatura argentina para compor seu personagem. Contudo, Inodoro surge para ser muito mais que um espelho do Martín Fierro, ainda que para isso seu criador recorra a uma linguagem já conhecida e bastante difundida na Argentina. O presente trabalho apresenta uma leitura de alguns episódios publicados nos primeiros anos de existência da série, a partir dos diálogos entre teoria literária e nova história política.

Palavras-Chave: História da Argentina. Humorismo ilustrado argentino. Representação do gaucho. História em quadrinhos. Inodoro Pereyra.

\footnotetext{
${ }^{1}$ Doutoranda do Programa de Pós Graduação em História da Universidade Estadual de Campinas (UNICAMP), sob a orientação do prof. Dr. José Alves de Freitas Neto. Mestre em História pela Unicamp e pela Universitat Jaume I, de Castelló de la Plana (Espanha). Pesquisa de mestrado desenvolvida com apoio Fapesp e Capes. Email: perecilapp@yahoo.com.br.
} 


\section{ABSTRACT}

This article intends to discuss the relationship between comics and literature through the analysis of the Argentine historieta Inodoro Pereyra, el renegau. This comic was created by the comedian Roberto Fontanarrosa for the magazine Hortensia as a parody of Gauchesca literature, radiotheater and Argentine folklore. Furthermore, the appereance of Inodoro Pereyra in Córdoba press in 1972 matchs with the celebration of the Martín Fierro poem’s Centenary, written by José Hernández. Therefore, it is not by chance that Fontanarrosa was inspired by this classical of Argentine literature to compose his character. However, Inodoro Pereyra arises to be much more than a mirror of Martín Fierro, even though his creator appeals to a known and widespread language in Argentine. The present work introduces a reading of some episodes published in early years of the comic, by across the dialogue with Literary theory and new political History.

Keywords: Argentine History. Argentine wit and humor. Representation of gaucho. Comic books, strips. Inodoro Pereyra.

\section{Inodoro Pereyra, um poema telúrico}

“Güenos días, Pereyra ¿Cómo andá?”, pergunta um paisano ao gaucho Inodoro Pereyra, ao que este responde: "Mal, pero acostumbráu" (FONTANARROSA, 1998: p. 405). Inodoro Pereyra, el renegau, é uma personagem da HQ argentina, que por lá eles chamam de historieta. Trata-se de um gaucho $^{2}$ que vive na região da Pampa Úmida, acompanhado de sua mulher e de um cãozinho que fala. Criado pelo desenhista rosarino Roberto Fontanarrosa, Pereyra surgiu na verdade como uma paródia de uma figura que tem uma longa história na cultura e nas letras argentinas: a figura do homem que percorre livremente os pampas, montado no seu cavalo.

A saga desde anti-herói campeiro começou em 1972, quando Don Inodoro apareceu pela primeira vez na revista Hortensia, publicação humorística da cidade de Córdoba. Nas suas primeiras aventuras, este gaucho se apresentava como um homem duro e de mau feitio, muito parecido ao Martín Fierro de José Hernández e aos gauchos perseguidos de Eduardo Gutierréz. No entanto, Pereyra mudará com o passar dos anos, e suas histórias se tornarão mais cômicas e caricaturescas.

A série foi publicada durante mais de 30 anos na Argentina e as personagens acabaram caindo nas graças do público, conquistando o seu carinho e apreço. Indo à Feria de Mataderos em

\footnotetext{
${ }^{2}$ Utilizarei ao longo do texto a grafia "gaucho" sem acento, para diferenciar do "gaúcho" brasileiro e de seu gentílico.
} 
Buenos Aires, por exemplo, pode-se comprovar a inconteste popularidade de Inodoro Pereyra, convertido em símbolo de uma das mais importantes feiras de artesanato e tradições populares argentinas. Enfim, trata-se de uma personagem bastante popular, comparável a própria Mafalda no que diz respeito ao reconhecimento pelo público-leitor. Mas, diferentemente da menina de Quino, os quadrinhos de Pereyra não conseguiram ser publicados fora da Argentina.

Aliás, é curioso que a obra de Fontanarrosa seja tão pouco conhecida no nosso país, haja vista que, exceto no caso de Inodoro Pereyra, outros personagens criados pelo Negro tiveram projeção fora da Argentina. Boogie, el aceitoso, por exemplo, foi publicado na Colômbia e no México, o que possibilitou que a violência delirante do personagem fosse difundida também por outros lados. Além disso, a produção gráfica de Fontanarrosa teve boa acolhida na Itália, Espanha e Nicarágua. No Brasil, chegou-se a publicar alguns dos trabalhos deste humorista, embora eles não tenham se popularizado tanto por aqui como ocorreu com os quadrinhos da Maitena, Quino e Liniers.

Entretanto, é preciso salientar que, mesmo ignorado no Brasil e sem tradução para o português, os quadrinhos de Inodoro Pereyra são uma excelente fonte para estudarmos a história da Argentina, particularmente no que se refere ao problema da identidade nacional e de sua interface com questões políticas e culturais. Neste sentido, estamos diante de uma documentação riquíssima, que permite ao historiador repensar questões cruciais do passado e do presente argentinos. As aventuras de Inodoro Pereyra são uma mescla de fina ironia com humor absurdo, recheadas de referências ao cancioneiro folclórico, ao radioteatro e à literatura gauchesca. Caracterizam-se, ademais, pela devastadora análise política, que é resultado da maneira inusitada como esta historieta trabalha temas relacionados à história deste país. Enfim, a saga da personagem pode ser definida como épica moderna, lúcida e irônica sobre a Argentina. Daí a sua atualidade e relevância histórica.

\section{Literatura gauchesca e $H Q$}

É sabido que na gênese da história das histórias em quadrinhos, muitos dos personagens dos comics tinham um claro vínculo com a literatura, como por exemplo, Tarzan, Dick Tracy e Fantasma. Isso talvez possa ser explicado pela própria especificidade da linguagem das HQs, que surgiram a partir da mescla entre cultura icônica e cultura literária e como um gênero híbrido entre a narrativa e a gráfica (SANTIS, 1998). Neste sentido, queremos problematizar neste artigo a relação entre quadrinhos e literatura, principalmente porque sabemos que o personagem Inodoro Pereyra é antes de qualquer coisa uma paródia de uma obra literária argentina. 
Criado no final de 1972 nas páginas da revista Hortensia, o gaucho Inodoro Pereyra, el renegau, nasceu como uma paródia do poema Martín Fierro (HERNÁNDEZ, 2008) do jornalista, escritor e político José Hernández. Tal e qual seu símile literário, Pereyra se apresentará nas suas primeiras aventuras como um homem duro e de mau feitio, prófugo da justiça e inclinado às brigas e perseguições policiais. O cenário de suas aventuras é as vastas planícies do interior argentino, o "mar de terra" onde teria se estruturado o mundo do gaucho rio-platense. As histórias do renegado transcorrem, portanto, num imenso espaço pampeano, metaforicamente definido como "deserto", lugar onde ele protagonizará uma série de peripécias e encontros inesperados com personagens oriundos do folclore, da literatura, dos mass media e da história argentina.

Mas as semelhanças entre "Seu Privada" e o gaucho hernandiano não param por aí. A aparição de Inodoro Pereyra na imprensa cordobesa coincide com o centenário da publicação do poema Martín Fierro, o que explica porque nas suas primeiras aventuras este gaucho de papel buscará sua identidade nos episódios vividos pelo personagem de Hernández. Tal escolha coloca el renegau na mesma fila dos clássicos gauchos-guapos-criollazos: Fierro - Vega - Moreira - Sombra - Covas - Pereyra (SASTURAIN, 1995, p. 195) . Além disso, nas suas primeiras histórias Don Inodoro será o protagonista de uma serie de situações que remetem ao modelo do "gaucho prófugo", do Martín Fierro, e à figura do "gaucho malo", consagrada em Sarmiento (SARMIENTO, 2004).

Sendo assim, a própria definição desta HQ como "poema telúrico" rende tributo ao poema escrito por Hernández, elevado à categoria de obra-prima da literatura argentina e monumentalizado pela geração do Centenário (ALTAMIRANO e SARLO, 1997). Quer dizer, Inodoro Pereyra surge como um comic em franco diálogo com os discursos sobre a identidade nacional, que põe em cena uma figura identitária cara à retórica do nacional-popular e pertencente ao imaginário social da nação. Levando isso em consideração, pode parecer que nosso gaucho não apresenta nada de novo em relação ao seu modelo literário e ao gênero gauchesco do qual ele é tributário.

Não obstante, Pereyra surge para ser muito mais do que um espelho do gaucho de Hernández. Neste sentido, este poema telúrico pode ser analisado como uma série na qual a história, antes que se repetir, confirma seu caráter excepcional. Nascido como uma paródia da literatura gauchesca, do radioteatro e do folclore argentino, os quadrinhos deste gaucho permitem que rediscutamos importantes questões que marcaram a história da República Argentina, tais como as oposições entre pampa e litoral, unitários e federais, nacionalismo e cosmopolitismo, e que compõem a imagem de uma nação dividida (SVAMPA, 1994).

Desta maneira, este artigo pretende cruzar os itinerários discursivos de Inodoro e personagens oriundas do campo literário, de modo a se reconstruir o dialogismo e a intertextualidade existente entre tais textos, além da polifonia que se instaura na enunciação 
deles (BAKHTIN, 1997). Quer dizer, nosso objetivo é apreender estas "outras vozes" que se intermesclam ao discurso destes personagens, e assim redimensionar a relação entre literatura e HQ.

Como toda HQ de humor, que trabalha sua mensagem humorística a partir de recursos como a condensação, o exagero, a aliteração, a antítese e o uso de estereótipos, os quadrinhos do gaucho Pereyra lidam com a linguagem do encoberto e do não-dito, operando a partir de deslocamentos semânticos e de duplos sentidos. Além disso, em se tratando de um discurso paródico que dialoga com uma infinidade de interlocutores, que vão de Sarmiento a Borges, do Martín Fierro de Hernández aos gauchos de Molina Campos, do problema agrário oitocentista às reivindicações socioambientais do Greenpeace, não é possível furtar-se também da tarefa de entender como funciona uma paródia, e qual a função do humor nestes quadrinhos.

\section{A paródia do nacional-popular nos quadrinhos de Inodoro Pereyra}

É preciso destacar que antes da criação de Inodoro Pereyra, existia toda uma tradição de HQs criollistas na Argentina, caracterizadas pelo tom nacional, costumbrista e pelos cenários bem ambientados. Esta historieta gauchesca apareceu nos anos 1930 como o corolário do reconhecimento tardio da figura do gaucho. "É notório o tom nacionalista (e preconceituoso em relação aos índios) de muitas destas tiras realizadas em tempos de nacionalismo e novas imigrações. Em geral, são quadrinhos bem ambientados, cruzados por referências a acontecimentos e personagens históricos, com roteiros que tentavam imitar a linguagem do campo e assumem com naturalidade a violência, as mortes e as arbitrariedades da autoridade" (GOCIOL e ROSEMBERG, 2000: pp. 28-29).

É interessante notar que a HQ gauchesca se constituiu na Argentina através do diálogo com as matrizes explicativas da história nacional, e a partir da retomada de modelos que integravam o imaginário político da nação. Neste sentido, abundam referências a acontecimentos históricos, como as campanhas do deserto, as disputas entre unitários e federais, a Guerra do Paraguai, etc. Observa-se, ademais, um forte vínculo entre estas historietas criollistas e o momento presente vivido pelos seus autores. Assim, a reivindicação da figura de Juan Manuel de Rosas feita pela HQ "El Huinca" não foi bem vista por alguns leitores, que acusaram seu criador de ter transposto para o quadrinho suas mal disfarçadas simpatias pelo peronismo - que, como se sabe, se dizia herdeiro do legado "nacionalista" propagado por Rosas. Da mesma forma, a exaltação da figura do "Güemes guerrilheiro" promovida por Oesterheld em 1971 na revista Epopeyas Argentinas talvez seja um prenúncio da filiação do roteirista à agrupação guerrilheira Montoneros, anos mais tarde. 
De qualquer modo, o retrato do gaucho feito por estes quadrinhos gauchescos abarca sua mais ampla tipologia - homem livre, peão, soldado, desertor, baqueano, domador -, embora a ênfase seja ainda a figura do gaucho errante (DEL CARRIL, 1993). Segundo Gociol e Rosemberg

[...] no modelo de historieta clássica impulsionada por Rapela, todos os episódios tem mais ou menos a mesma estrutura: sempre há algum mal-entendido que põe em perigo a vida do gaucho e tudo parece andar irremediavelmente mal até que, de um momento a outro [...] a situação se reverte e então o herói demonstra ser invencível. E ali é visto, uma vez mais, ao final da aventura: um gaucho de nanquim, a galope, numa inalcançável planície de papel (GOCIOL e ROSEMBERG, 2000, p. 290).

Entretanto, é importante ressaltar que a grande diferença entre os gauchos consagrados pela historieta gauchesca de então e a personagem criada por Roberto Fontanarrosa é que esta última é antes de mais nada uma paródia. Nos quadrinhos de Inodoro Pereyra não há o tom nacionalista, a exaltação do arquétipo e a narrativa exemplar e didática. Além disso, a paródia construída pelo Negro não se dirige contra a HQ gauchesco-nativista ${ }^{3}$ anterior, que teria surgido em 1928 com o índio Patoruzú ${ }^{4}$, e que envolveria todas estas personagens gauchas elencadas, além de outras indígenas. Ou seja, Inodoro Pereyra não foi uma paródia intra-genérica (ROMANO, 1991). Pelo menos, não a princípio.

Em suma, como paródia inter-genérica contra certo discurso gauchesco-nativista, os quadrinhos criados pelo Negro Fontanarrosa satirizam não a historieta gauchesca em si, mas sim certo nacionalismo em voga durante os anos de criação de Inodoro Pereyra. Trata-se de um discurso sobre o nacional bastante difuso por aqueles anos, e que ia das versões mais reacionárias do criollismo até a música de protesto dos anos 1960. Neste sentido, Fontanarrosa construiu sua paródia a partir de três alvos principais, a saber, a literatura, o folclore e o radioteatro gauchescos. É este tema que será tratado nas próximas páginas.

\section{Um gaucho cantor}

Nas primeiras décadas do século XX na Argentina, o gaucho reivindicado pela geração do Centenário como símbolo de argentinidade foi o gaucho cantor, aquele que anonimamente

\footnotetext{
${ }^{3}$ Neste gênero se incluem as histórias de índios e as de gauchos.

${ }^{4}$ Patoruzú é uma HQ humorística criada por Dante Quinterno que tem como protagonista um índio patagônico, algo um pouco raro na história da historieta argentina. Trata-se do último tehuelche, um indiozinho agauchado e rico, e que se tornou uma das personagens mais populares e polêmicas dos quadrinhos deste país. Cf: STEIMBERG, Oscar. Leyendo Historietas. Nueva Visión: Buenos Aires, 1977.
} 
deambula pelo pampa chorando seus males em solidão. Com efeito, o cantor é uma das figuras chaves da literatura gauchesca, e seu canto sustenta o edifício sobre o qual estão assentadas as convenções do gênero. Apesar de toda sua visão negativa sobre o gaucho argentino, Sarmiento não pôde deixar de comparar o gaucho que canta com os bardos da Idade Média, reconhecendo a qualidade poética de suas composições. No Martín Fierro, canto e vida são uma única coisa: o gaucho vive para cantar e canta para viver, e não deixa de ser simbólico que no momento em se efetua a travessia da fronteira, Fierro quebra seu violão. Enfim, o trecho abaixo extraído do poema de Hernández ilustra muito bem a importância do canto para a conformação do gênero gauchesco.

Aquí me pongo a cantar, al compás de la vigüela que al hombre que lo desvela una pena estrordinaria, como el ave solitaria con el cantar se consuela.

(HERNÁNDEZ, 2010)

No entanto, nos quadrinhos de Inodoro Pereyra, esta função poética ligada ao canto é ridicularizada e desmistificada. $O$ gaucho de Fontanarrosa até que tenta cantar, mas no geral ele desafina horrivelmente. Sua pena extraordinária está mais para pena ordinária. Vejamos os quadrinhos a seguir.

Figura 1 - "Recital"

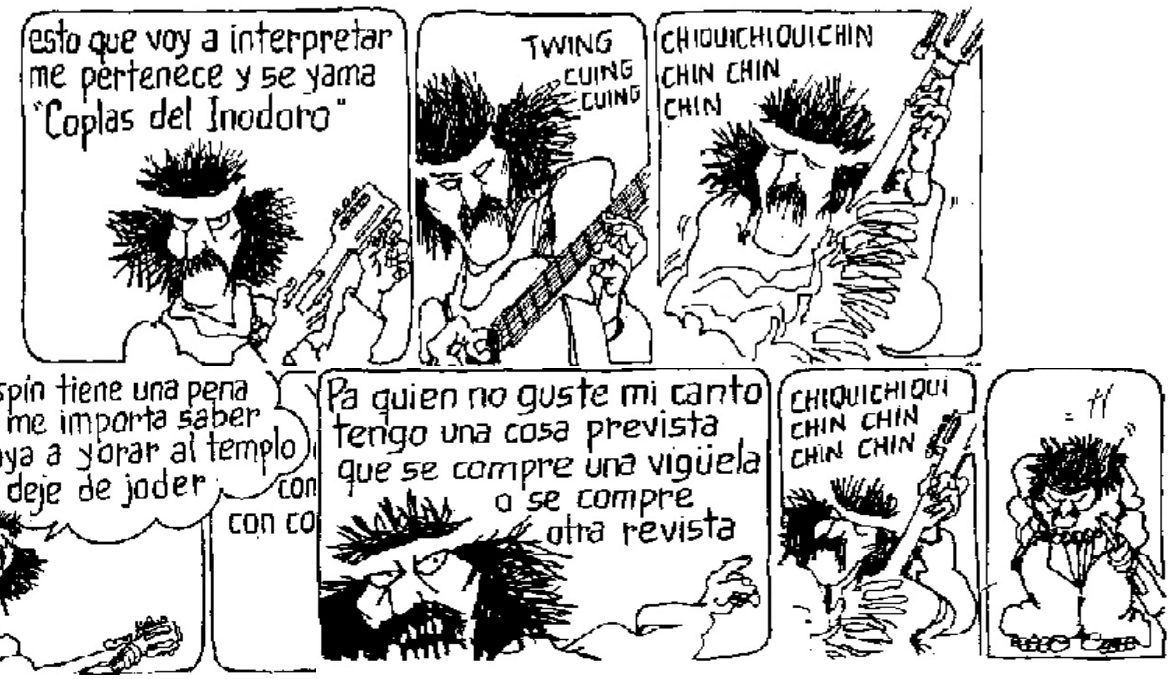

Fonte: Hortensia, $n^{\circ} 41$, setembro de 1973, p. 17. 
Nesta sequencia, é muito interessante a consciência performática que a personagem parece ter, e que contraria totalmente a ideia do canto como uma característica intrínseca e natural ao gaucho, e não uma mera habilidade que poderia ser desenvolvida. Inodoro Pereyra parece cantar diante de um grande público, exibindo seus melhores dotes como cantor. Ele faz improvisações, dedilha alucinadamente as cordas de seu violão, faz caras e bocas... Ou seja, desnaturaliza-se a ideia de que o gaucho seria um cantor nato, já que a seqüência brinca com a questão do artifício e da natureza em relação ao canto. Contudo, as onomatopéias e a anatomia expressiva da personagem não dão lugar a dúvida: nosso gaucho é um tremendo de um desafinado e parece não se importar muito com isso. "O crespín tem uma pena, que não me importa em saber, que vá chorar no templo e pare de encher o saco". Além disso, nestas "coplas de Inodoro", parece recordar-se que música e canto são questões mediatizadas pelo mercado, como o renegau deixa claro no final: "Pra quem não gosta do meu canto, tenho uma coisa prevista, que compre outra vigüela ${ }^{5}$ ou que compre outra revista".

Já no episódio "Payada con un negro" é retomado o mesmo tema do duelo entre Martín Fierro e o Negro, que desta vez tem nome: "Mandinga". Assim como seu símile da literatura, também Inodoro se mostra preconceituoso com o payador mulato, “- Que eu saiba os índios são conhecidos por "infiéis", mas os negros são reconhecidos apenas pela cor", o que nos faz lembrar das palavras de Fierro: “-A los blancos hizo Dios,/ a los mulatos San Pedro,/ a los negros hizo el diablo/ para tizón del infierno" (HERNÁNDEZ, 2010, cap. 7).

Inicia-se, então, a payada. Mandinga se mostra bastante virtuoso nas composições de seus versos, e parecia que ganharia do gaucho: “-Quem pode diferenciar um bidê de uma Privada?", diz em tom desafiador. "A pergunta era um golpe baixo. Um furúnculo telúrico pareceu brotar no bordão de Inodoro". O gaucho, então, ataca: "Não posso cantar com este violão que está com as cordas desafiadas, a boca quebrada e as cravelhas bichadas". Mais uma vez o negro se sai bem: "Vá ao violeiro. Proteste pelas cordas, proteste pela boca, proteste pelas...”. Inodoro, então, arremata: “O quê? Nunca ouviu falar dos cantores de protesto, caralho?".

\footnotetext{
${ }^{5}$ A viola do gaucho.
} 
Figura 2 - "Payada con un negro"

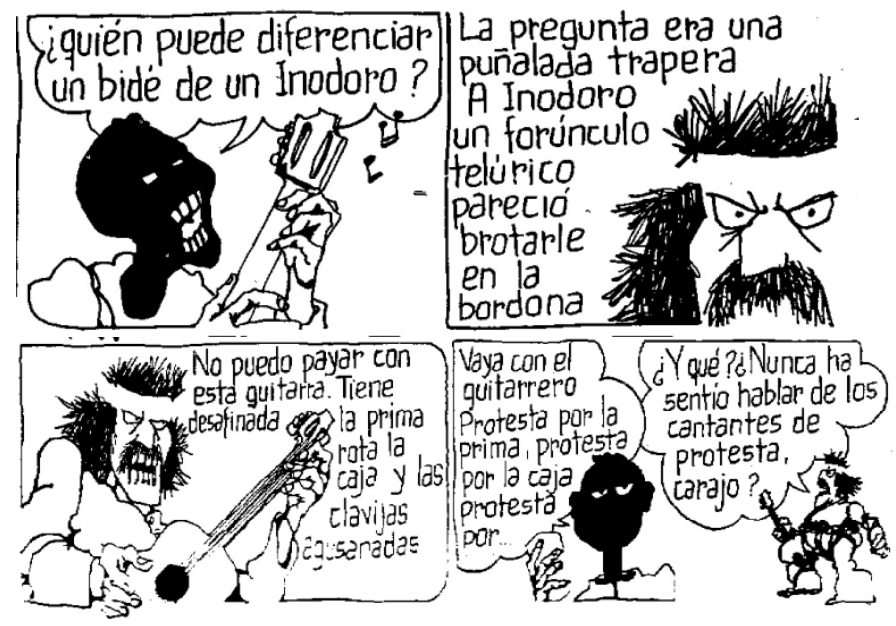

Fonte: Hortensia, $\mathbf{n}^{0}$ 39, agosto de 1973, p. 6.

Em "Payada con un negro", encontramos referências à literatura gauchesca através do Martín Fierro, ao folclore argentino através da lenda do Mandinga $^{6}$, e à música de protesto dos anos 1960 e 1970. Ademais, neste episódio observa-se que Inodoro Pereyra, além de não ser um cantor típico, tampouco é um exímio payador ${ }^{7}$, já que o negro lhe vence facilmente no duelo de violas. Contudo, o mais divertido desta sequencia é que a suposta braveza do gaucho representada no quadrinho em que Inodoro está com o olhar crispado de cólera e no qual temos uma interferência do narrador ("A pergunta era um golpe baixo. Um furúnculo telúrico pareceu brotar no bordão de Inodoro") - é desconstruída no arremate final da historinha: Inodoro surpreende com a saída genial expressa na última vinheta ("-O quê? Nunca ouviu falar dos cantores de protesto, caralho?"). Ou seja, diante do desafio proposto por Mandinga, Pereyra se acovarda, abranda. O cenho frunzido da personagem indicado pelo close-up do segundo quadrinho se desanuvia no último através de um plano inteiro, onde não há mais sombras de furúnculos telúricos.

De qualquer forma, mesmo sendo um cantor bem às avessas, Inodoro Pereyra não deixa de cantar, servindo-se para tanto dos muitos modelos oferecidos pela história argentina relacionados ao gaucho cantor. Da literatura gauchesca à música de raíz folclórica, o amálgama canto e nação se faz presente e o renegau não poderia ignorar este fato. Armando Tejada Gómez costumava dizer: "Cantando hei de opinar", retomando assim um dos refrões do Martín Fierro: "canto opinando que es mi modo de cantar" (HERNÁNDEZ, 2010, p. 69). Enfim, mesmo cantando

\footnotetext{
${ }^{6} \mathrm{Na}$ Argentina, trata-se de uma figura do folclore representada pela cor e roupas negras. Também pode significar "diabo", "menino travesso".

${ }^{7}$ Improvisador ou pessoa que memoriza poemas e rimas
} 
mal, Pereyra rende tributo ao topos do gaucho que canta, o que nos faz lembrar da canção composta por Horácio Guarany e interpretada por Mercedes Sosa em 1977: "Si se calla el cantor calla la vida/ porque la vida, la vida misma es todo un canto".

Figura 3 - Capa da composição "Si se calla el cantor"

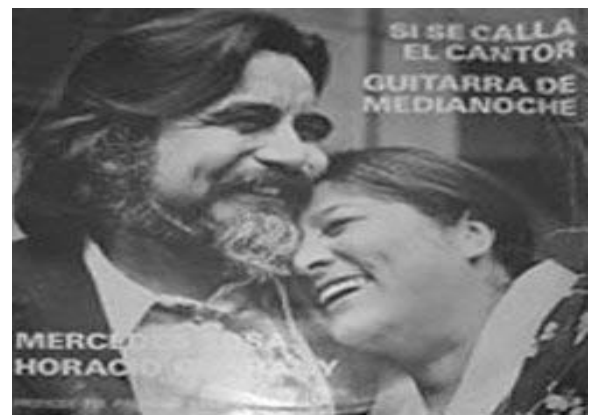

Fonte: Horacio Guarany \& Mercedes Sosa, 1977.

\section{Um gaucho malo}

Além do modelo do gaucho cantor, os quadrinhos de Inodoro Pereyra também brincam com o protótipo do gaucho malo cunhado por Sarmiento. Em "Silencio y muerte de um maboretá" Fontanarrosa se refere a este modelo parodiando a seguinte passagem do Martín Fierro, "iYo juré en esa ocasión/ ser más malo que una fiera!" (HERNÁNDEZ, 2010, cap. 6). Tal frase foi dita pelo gaucho de Hernández depois da sucessão de desgraças ocorridas na sua vida: após desertar do exército e encontrar o seu rancho vazio, sem sua mulher e sem seus dois filhos, ele decide deixar de ser manso para se tornar gaucho matrero. No episódio em questão, Don Inodoro afirma já no primeiro quadrinho: "Hoje quero ser injusto", explicando em seguida suas razões para isso: "porque cresce em mim o mosto socavão e cereal, planetário e caudaloso, o anelado encanto, feroz, ecumênico e réptil do protesto. Me retorce a índole rumorosa, subversiva e turva de uma matilha impudente, incendiada por borrachudos febris e raivosos. Por que a falsa difteria levou de mim o meu melhor porco? Por que a desgraça me açoita desse jeito? Não existe Deus para o gaucho pobre". Neste sentido, o leitor fica sabendo que tal e qual o Martín Fierro, o renegau também tem uma vida repleta de "desgraças": no caso, o seu porquinho teria morrido por uma difteria. Todavia, o ato de injustiça cometido pelo gaucho para aliviar seu sofrimento não é matar a um negro e se meter em brigas, como o faz seu símile literário. A injustiça que comete Inodoro Pereyra é simplesmente matar com uma pisadela a um louva-a-deus (mamboretá), o que produzirá um sonoro "Crunch" 
Figura 4 - "Silencio y muerte de un mamboretá".

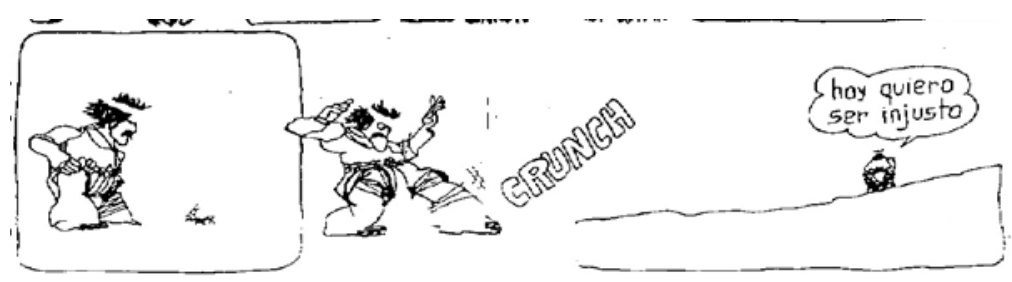

Fonte: Hortensia, $\mathbf{n}^{\circ}$ 35, junho de 1973, p. 18.

Aliás, esta mesma cena presente na Ida do Martín Fierro (Canto VI) é parodiada no episódio "Pa qué mentar mi tapera". Nele Inodoro decide voltar para o seu rancho após três dias longe de casa. Com intuição baqueana, seu cavalo criollo o leva até seu pago ${ }^{8}$ com muita má vontade e a galope curto, mas chegando lá não encontram ninguém, nem o Mendieta, nem a Eulogia, nem nada. Inodoro se desespera: “Que ventos me castigaram para eu ficar tão pobre?". No entanto, o personagem coloca as mãos no queixo de modo pensativo e conclui: "Eita. Este não é o meu rancho". O gaucho, então, dirige-se ao seu flete ${ }^{9}$, dizendo: "Onde me trouxeste porqueira de animal?". O episódio termina com a inserção de um balão de pensamento e a antropomorfização do cavalo, que pensa: "Pelo que me dá de comer, o que ele queria? Uma excursão guiada?".

Figura 5 - "Pa que mentar mi tapera"

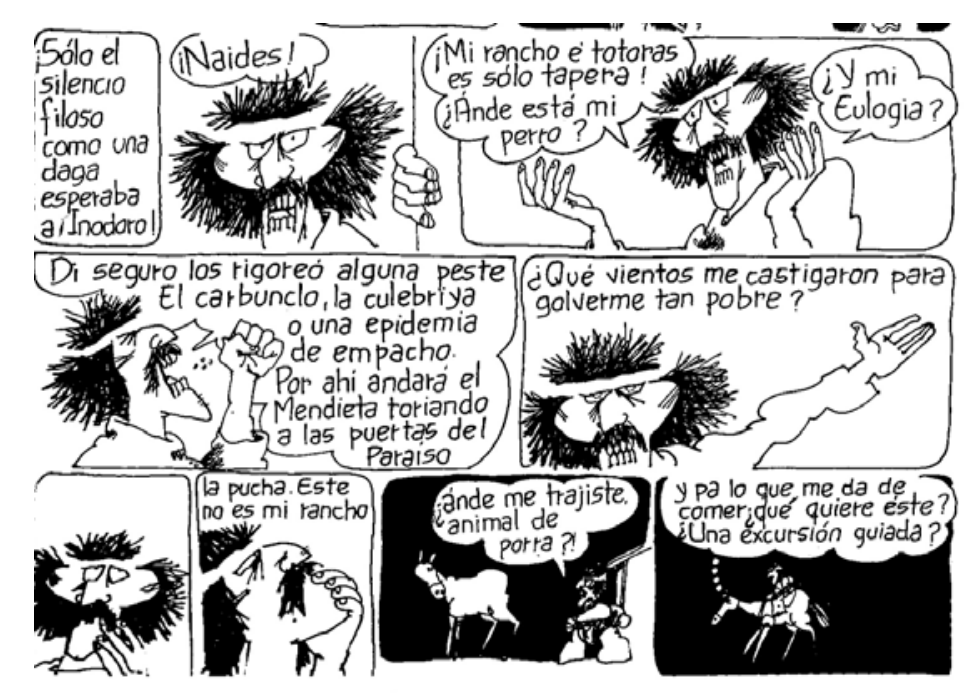

Fonte: Hortensia, ${ }^{\circ}$ 57, julho de 1974, p. 4.

\footnotetext{
${ }_{9}^{8}$ Lugar onde a pessoa nasceu; vilarejo, querência.

${ }^{9}$ Um dos nomes do cavalo do gaucho.
} 
Voltando à paródia do gaucho malo e aos limites da valentia do nosso gaucho, são ilustrativos os episódios "Eulogia", "El leonero" e "El Escorpión Resolana". No primeiro, temos a cena do seqüestro da Eulogia pelo renegau. Quando o pai da moça, caracterizado como uma "coruja pampeana" de tão bravo que era, percebe que sua filha estava sendo cortejada pelo gaucho, a coisa se complica. Então, Pereyra se enche de valentia para enfrentar ao pai da Eulogia, e como um "malón10 ébrio de argentinidade", parece se preparar para demonstrar suas destrezas gauchas. Tudo indicava que haveria um duelo entre o gaucho e a "coruja pampeana", mas de maneira inesperada o renegau começou a dançar um malambo, dança masculina de sapateado muito tradicional entre os gauchos argentinos. Por causa disso, subiu uma nuvem de poeira, que acabou facilitando o seqüestro da prenda11 sem que Pereyra fosse notado. Quando o pai da chinoca se dá conta que sua filha foi raptada, cita um trecho da canção de Castilla, La Pomeña: "Por que te roubam, Eulogia, carnavaleando?" Quer dizer, a tensão narrativa gerada pela iminência de um combate é quebrada exatamente pela não ocorrência do combate, produzindo o efeito humorístico da historieta. Mais uma vez, vemos que a cara amarrada da personagem e a indicação de seu caráter feroz é desmentida pela própria ação de Inodoro, que afrouxa.

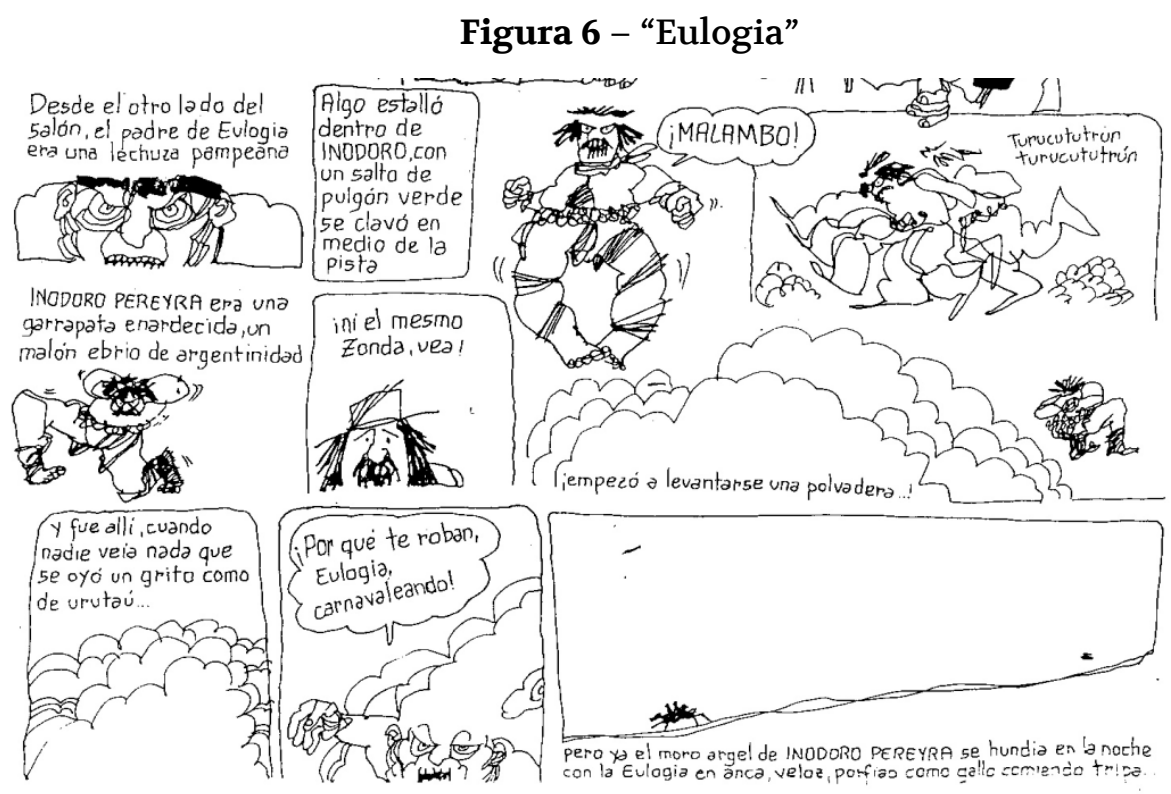

Fonte: Hortensia, $\mathrm{n}^{\circ}$ 28, fevereiro de 1973, p 16.

Em "El Leonero", Inodoro Pereyra é contratado para caçar um leão, por causa da fama que teria de gaucho destemido e mau. Contudo, quando se depara com toda a ferocidade do animal, o

\footnotetext{
${ }^{10}$ Incursões indígenas inesperadas que tinham o objetivo de roubar gado e levar mulheres brancas cativas; empresas econômicas militarizadas organizadas por grupos indígenas fronteiriços.

${ }^{11}$ A mulher do gaucho; china.
} 
personagem dá um passo atrás, monta no seu cavalo e volta com uma pele de gato, justificando-se que "o leão teria apequenado quando o viu".

Figura 7 - "El leonero".

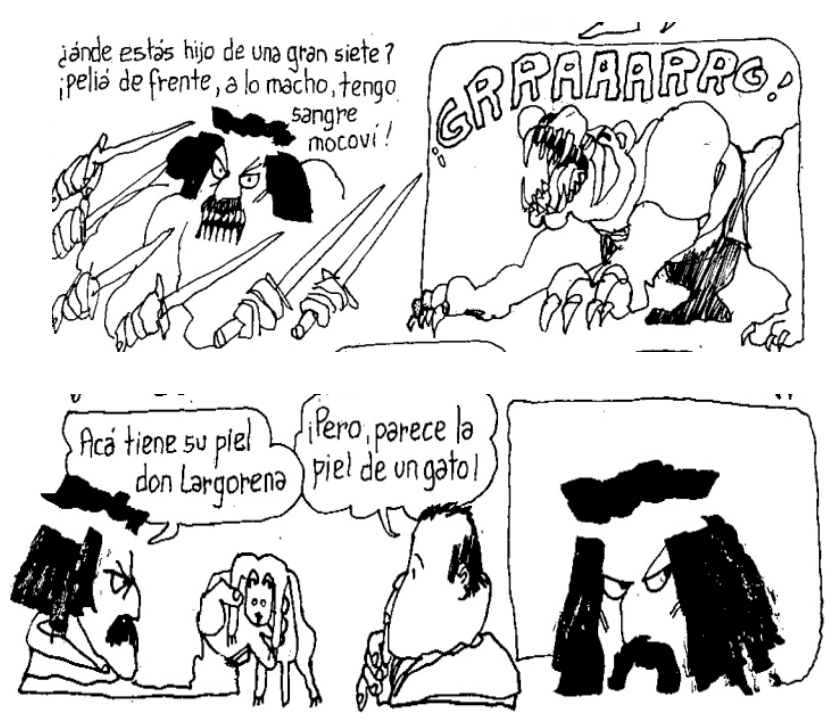

Fonte: Hortensia, $\mathrm{n}^{\mathrm{0}}$ 31, abril de 1973, p. 15.

Finalmente, no episódio "El Escorpión Resolana" Pereyra é convocado para pedir a um valentão que estava andando pelo pago para que fosse embora. Tratava-se de Escorpión Resolana, o famoso cuteleiro criado como homenagem à música de Jaime Dávalos "Resolana". Inodoro chega intimando o valentão: "O senhor deve ser o Escorpión Resolana, mas vou te pedir uma coisa, aparcero". Sem entender muito bem o propósito da vinda do renegau, Resolana começa a contar a sua história: "uma patrulha me perseguia porque eu havia feito um filho macho na china do delegado, tinha queimado o rancho e tinha degolado os três gurisinhos e uma viscacha ${ }^{12}$ mulherenga que tinha. Roubei um puma e fugi montado no leão metade fatia e metade rodela usando como chicote uma jararaca que prendi rapidamente. Mas o puma começou a mancar de repente. Descasquei o ferro e veio tipo uns porcos para o milho. Eram treze e eu, que sou meio supersticioso, acabei tirando as vísceras de todos na bagunça. Depois depenei um cavalo. E com o sangue fiz um brinde ao mesmo Satanás". Após este relato de atrocidades, Resolana pergunta a Inodoro: "Gostarias de me pedir mais alguma coisa"?", ao que este responde: “ Um autógrafo...". Quer dizer, se Inodoro Pereyra era mau, Escorpión Resolana seria o triplo, o que fica evidente na comparação do traço das duas personagens: este último tem seu traçado ainda mais forte e

\footnotetext{
${ }^{12}$ Pequeno roedor de hábitos noturnos próprios das regiões de planície, da mesma família da chinchila.
} 
expressivo do que o do gaucho, com destaque para a sua dentição medonha e para o cabelo e barba bastante densos, formando praticamente uma única coisa.

Figura 8 - "El Escorpión Resolana"

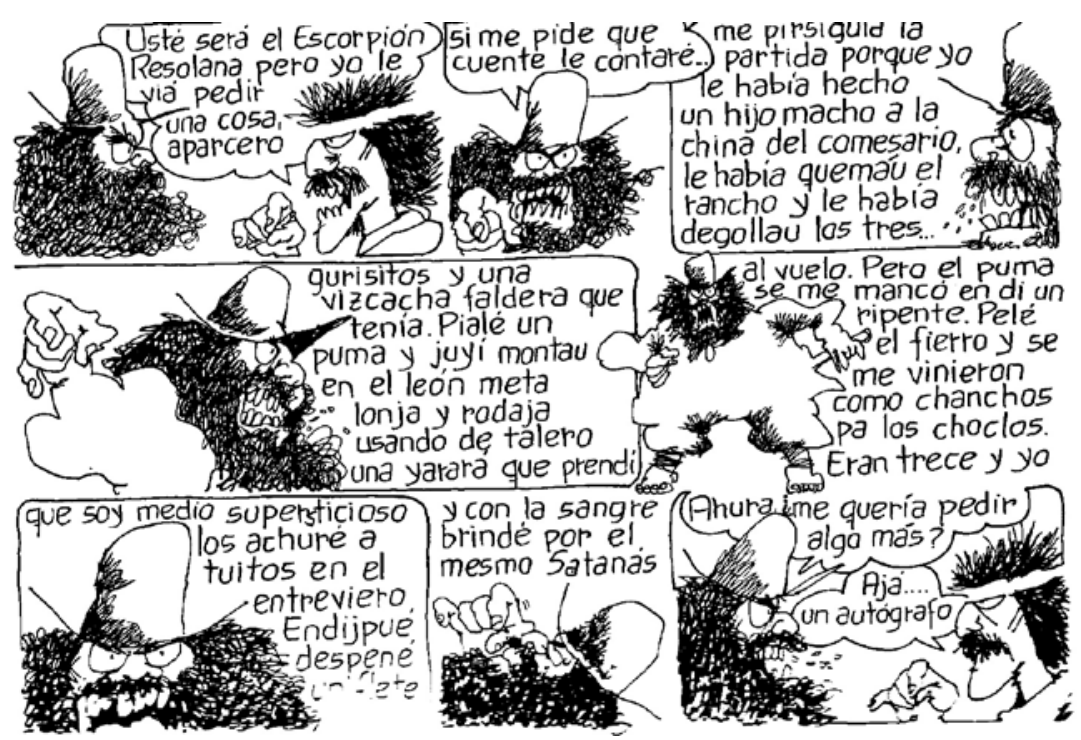

Fonte: Hortensia, n $^{\circ}$ 58, julho de 1974, p. 19.

Resumindo: a enunciação da valentia e do caráter malevo da personagem Inodoro Pereyra, feita através do seu traço forte e carregado, de sua expressão séria e carrancuda e das descrições hiperbólicas oferecidas pelo narrador, são desconstruídas a todo o momento no próprio desenvolvimento das historinhas. Diante de situações perigosas, o gaucho abre mão de sua braveza para colocar em ação sua picardia crioya ${ }^{13}$, mais apropriada para alguém que precisa sobreviver e que, para tanto, prefere poupar-se. Não que Inodoro Pereyra seja um covarde. Pelo contrário, Pereyra é um gaucho indômito e destemido como os anteriores, à diferença de que, por causa de seu caráter de anti-herói, seu heroísmo em geral se converte em fracasso. Ou pelo menos, seu heroísmo perde a sacralidade. Não se pode ser herói sempre...

\footnotetext{
${ }^{13}$ Conceito que se refere a características que supostamente pertenceriam ao criollo: malandragem, astúcia e capacidade de improvisar.
} 


\section{Inodoro Pereyra e seus Outros}

O mundo do gaucho se estruturou na literatura gauchesca sempre em função de seus Outros, por antonomásia. Este "outro" poderia ser o estrangeiro, o negro ou o habitante da cidade, embora mais tradicionalmente a alteridade recaia no elemento indígena.

Neste sentido, só se compreende o tipo de identidade reivindicada para o gaucho levando em consideração seus Outros. No Martín Fierro, por exemplo, este Outro não tem valor absoluto, já que sua apreciação depende das contingências históricas do momento, e das variáveis conjunturais que o poema registra. Isso explica porque na $I d a$, escrita em 1872 num contexto de muitas críticas à política imigratória, o grande Outro em relação ao gaucho é o gringo e não o índio. Na Volta em contrapartida, e já na esteira da bem sucedida "Campanha do Deserto", as coisas se invertem: a vida nos $\operatorname{toldos}^{14}$ teria sido muito pior para Martín Fierro do que a vida nos fortines $^{15}$, "inferno menor que se converteu o território cristão". Logo, o indígena aparece aqui totalmente desumanizado, ícone da barbárie em seu estado puro. Inclusive, é significativo que, ao fazer suas contas com a justiça, Martín Fierro não computa aos indígenas que matou. "A resposta é óbvia: não entram porque estão do outro lado da fronteira, fora do alcance da lei. Neste sentido, o índio é sim o outro absoluto, e seu estatuto de fora da lei o separa tanto de gauchos como de gringos e inclusive de negros" (ANSOLABEHERE, 2008: p. 253).

Nos quadrinhos de Inodoro Pereyra também a presença destes Outros é recorrente, porém de modo geral eles aparecem deslocados, em contextos e situações não familiares, o que acaba desestabilizando os pólos identidade e alteridade, construídos historicamente e imbuídos de grande força simbólica. No episódio "Vergüenza gaucha", Inodoro Pereyra é assediado sexualmente por uma portenha que estava entediada diante da ausência do marido, e só recusa o tentador convite porque a senhora o trata com esnobe superiorioridade. $O$ mais engraçado deste episódio é que ele inverte o sentido de uma cena recorrente na história argentina, na qual é o campo quem assedia a cidade, e não o contrário ${ }^{16}$. Contudo, em "Vergüenza gaucha" é a cidade quem assedia o campo, o que tem um peso significativo em relação à modificação das pautas da gauchesca.

\footnotetext{
${ }^{14}$ Barraca dos indígenas, feita de ramas e couros.

${ }^{15}$ Fortaleza militar; pequeno forte.

${ }^{16}$ Isso se dá através de incursões de malones e das ameaças representadas por exércitos de cavaleiros gauchos, como é o caso da mazorca e das montoneras.
} 
Figura 9 - "Verguenza gaucha"

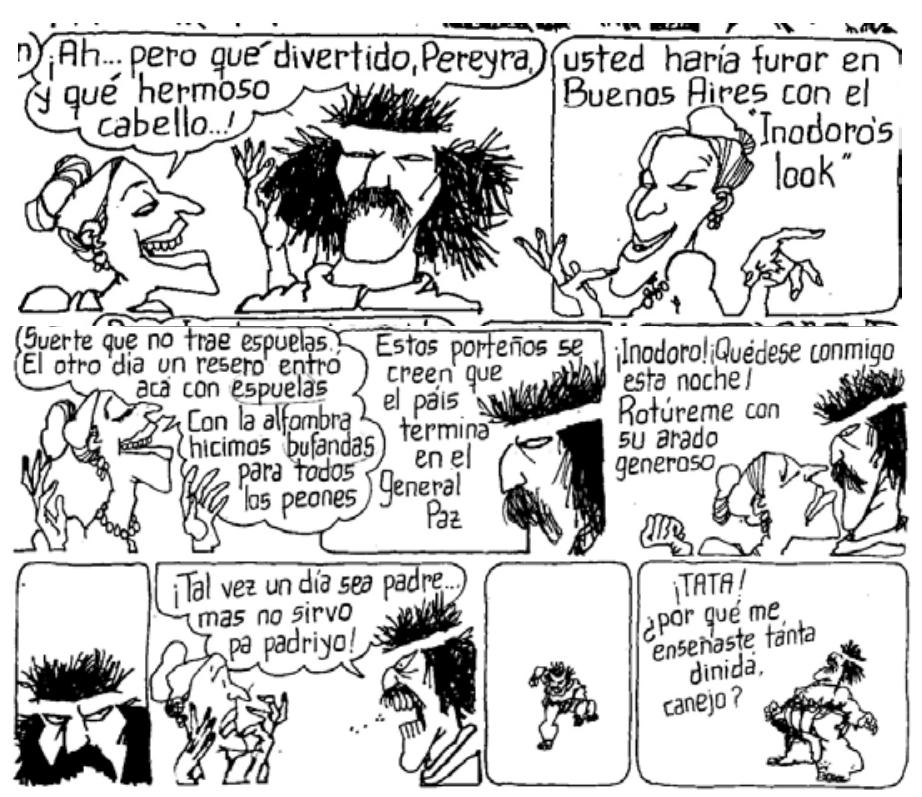

Fonte: Hortensia, $\mathrm{n}^{\mathrm{o}}$ 40, agosto de 1973, p. 19.

$\mathrm{Na}$ história "El peludo incandescente" temos mais um encontro entre Pereyra e gente vinda de Buenos Aires. Mais precisamente, era um casal que queria comprar o rancho do renegau a fim de montar uma peña ${ }^{17}$, um centro tradicional que se chamaria "El peludo incandescente". Contudo, Pereyra não aceita de jeito nenhum a proposta oferecida, fazendo um discurso exaltado em defesa da não comercialização do seu rancho de adobe, levantado por ele mesmo, com suas próprias mãos gauchas Assim, Don Inodoro afirma o seguinte, parodiando a canção "Como yo lo siento" de Osiris Rodriguez Castillo: "Nãooo. Não me venha comercializar meu rancho com olhos de forasteiro porque não é aquilo que aparenta, mas sim como eu o sinto". O casal portenho acaba indo embora e a história termina com a seguinte fala de Inodoro Pereyra, que contradiz tudo o que ele havia dito anteriormente: "Que peña que nada... Aqui o que é preciso colocar é um 'caféconcert"'.

\footnotetext{
${ }^{17}$ Agrupação de que se reúne a fim de promover festas populares de raiz folclórica.
} 
Figura 10 - El peludo incandescente

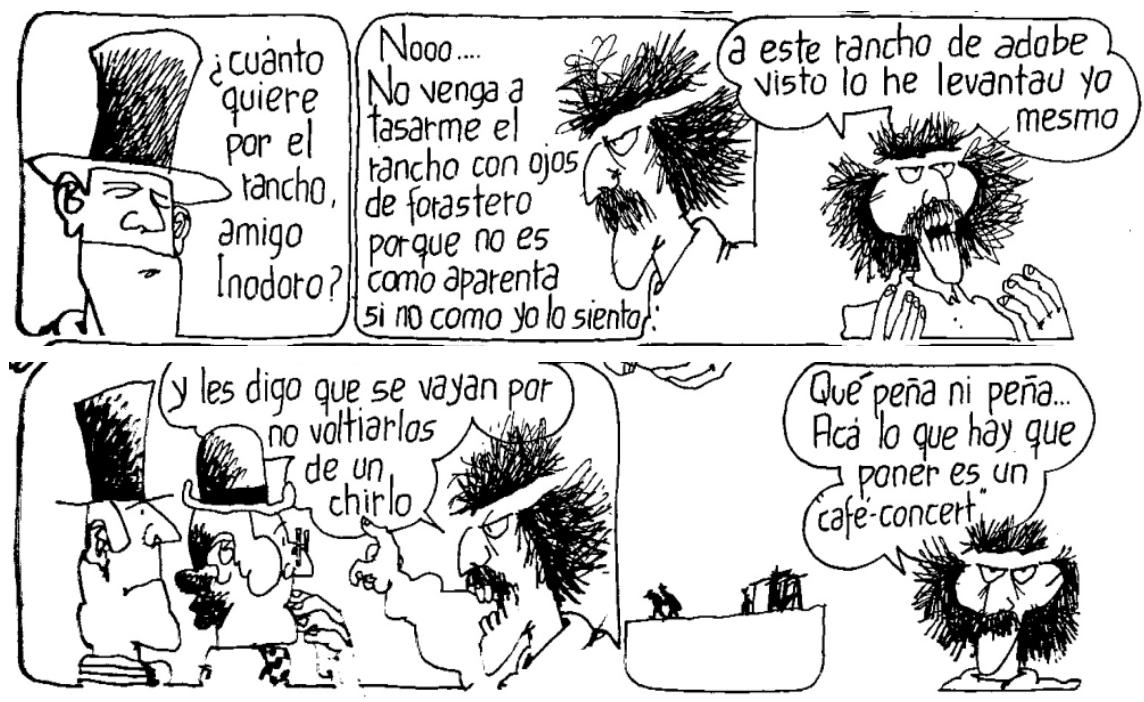

Fonte: Hortensia, ${ }^{\circ}$ 51, março de 1974, p. 19.

Já no episódio “¿Donde vas, gringo?”, temos um encontro entre Inodoro Pereyra e uns turistas de fala inglesa. A história é totalmente construída a partir da dupla narrativa, dividida entre a visão do gringo/ a visão do gaucho. Pois ao passo em que o primeiro se aproxima de Don Inodoro imbuído de uma concepção totalmente essencialista e preconceitusa sobre o que seria o gaucho argentino, Pereyra esboça unicamente um incômodo silêncio cujo sentido só será revelado no último quadrinho: o gaucho diz que não entendia porque se vinha de tão longe se se vinha inutilmente. No entanto, ele enuncia esta ideia tomando de empréstimo a letra do cantor uruguaio Alfredo Zitarosa, "La vuelta de Obligado"18.

\footnotetext{
${ }^{18}$ Qué los parió los gringos/ Una gran siete;/ Navegar tantos mares,/venirse al cuete,/ qué digo vernirse al cuete.
} 
Figura 11 - ¿Dónde vas, gringo?”

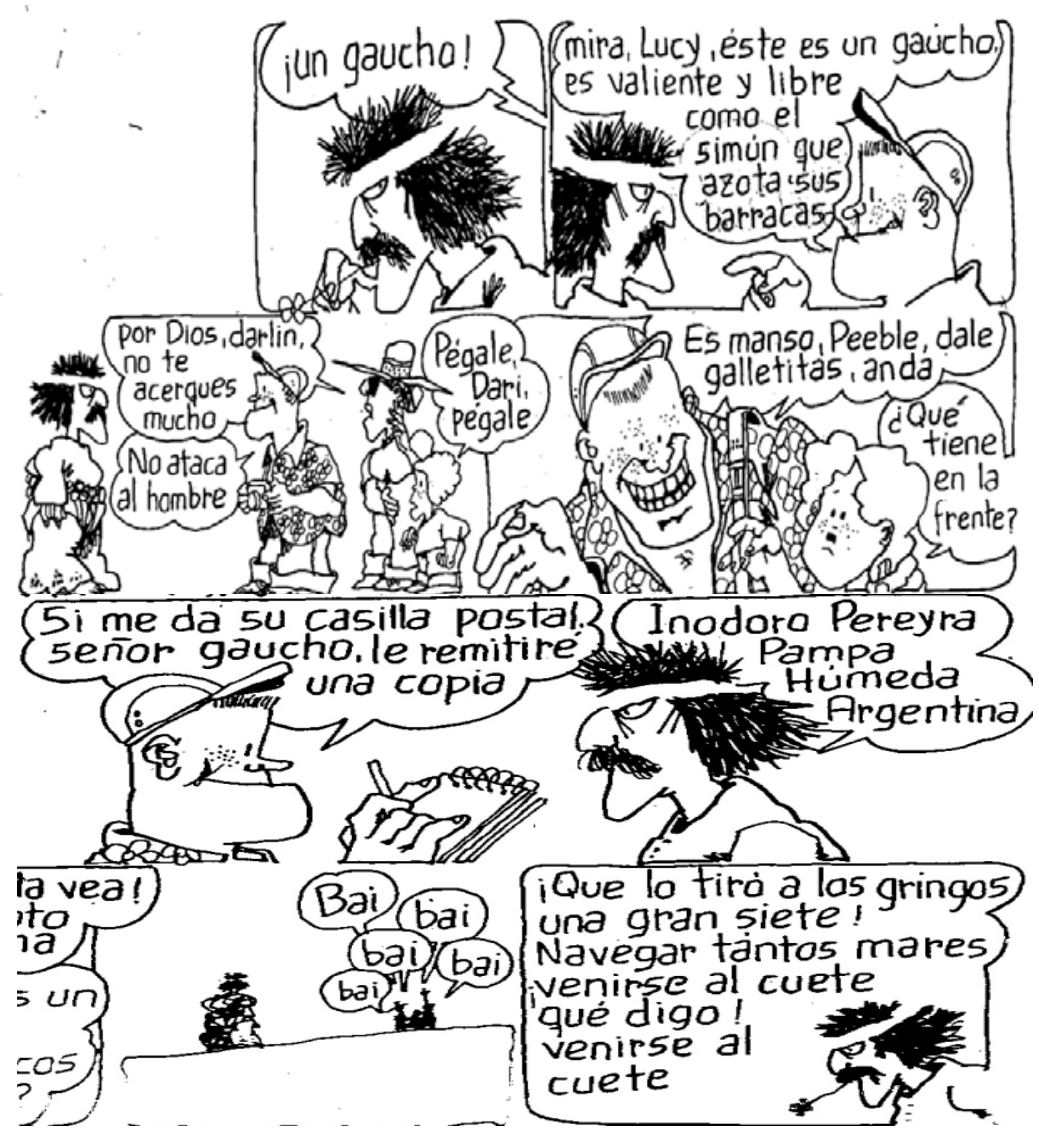

Fonte: Hortensia, $n^{\circ} 48$, janeiro de 1974, p. 4.

De modo geral, os encontros entre Inodoro Pereyra com estrangeiros costumam repetir esta mesma estrutura sugerida pelo episódio “¿Donde vas, gringo?”. Neste sentido, ocorre uma série de mal entendidos e falas desencontradas entre gaucho e gringo, de modo que isso produza o efeito humorístico. Nos quadrinhos do renegau, o conceito de gringo também abarca uma ampla tipologia, que vai dos turistas brasileiros à Yon Darwin, dos charros mexicanos ao Zorro. Às vezes sua representação gera simpatia no leitor; em outros momentos, repúdio.

Finalmente, vejamos como se dá a representação do indígena nos quadrinhos de Inodoro Pereyra. Tal e qual sucede com os outros Outros de Inodoro Pereyra, também o índio aqui aparece em contextos deslocados, protagonizando situações clássicas em um cenário modernizado e midiatizado pelo mercado e pela cultura massificada. Às vezes é mostrado como comparsa do gaucho, ou pelo menos, o percebemos inofensivo, como se nota na frase com que costumam cumprimentar ao renegau: “¿Cómo andái, Inodoro toro y vó Mendieta perro?”; em outros 
contextos, a imagem que predomina é do indígena como o selvagem, o Outro em relação ao gaucho, tal e qual a literatura argentina o consagrou (MANDRINI, 2003). Por exemplo, em "Malón de ausencia", dá-se o encontro entre Pereyra e três índios. A princípio, a aproximação entre os dois lados não é em nada amistosa: "Huinca ${ }^{19}$ matando, huinca matando". Um deles se apresenta: "Somos o malón das quartas-feiras", ao que Inodoro redargue: "Um malón? E por que são tão poucos?". A resposta do indígena é de grande hilaridade: "É que somos um malón de ausência". Ou seja, Fontanarrosa retoma um tema bastante presente na cultura argentina oitocentista, mas o inverte totalmente: se de um lado temos o topos das incursões indígenas que avassalavam as povoações brancas da fronteira, por outro vemos que se trata de um malón de ausência, que necessita inclusive pedir uma ajuda para o gaucho, através da compra de uma rifa que custearia a viagem dos indígenas até o forte que seria atacado. A conclusão de Don Inodoro não deixa de ser cômica: "P... que o pariu...! Os pampas andam perigosos".

Figura 12 - "Malón de ausencia".

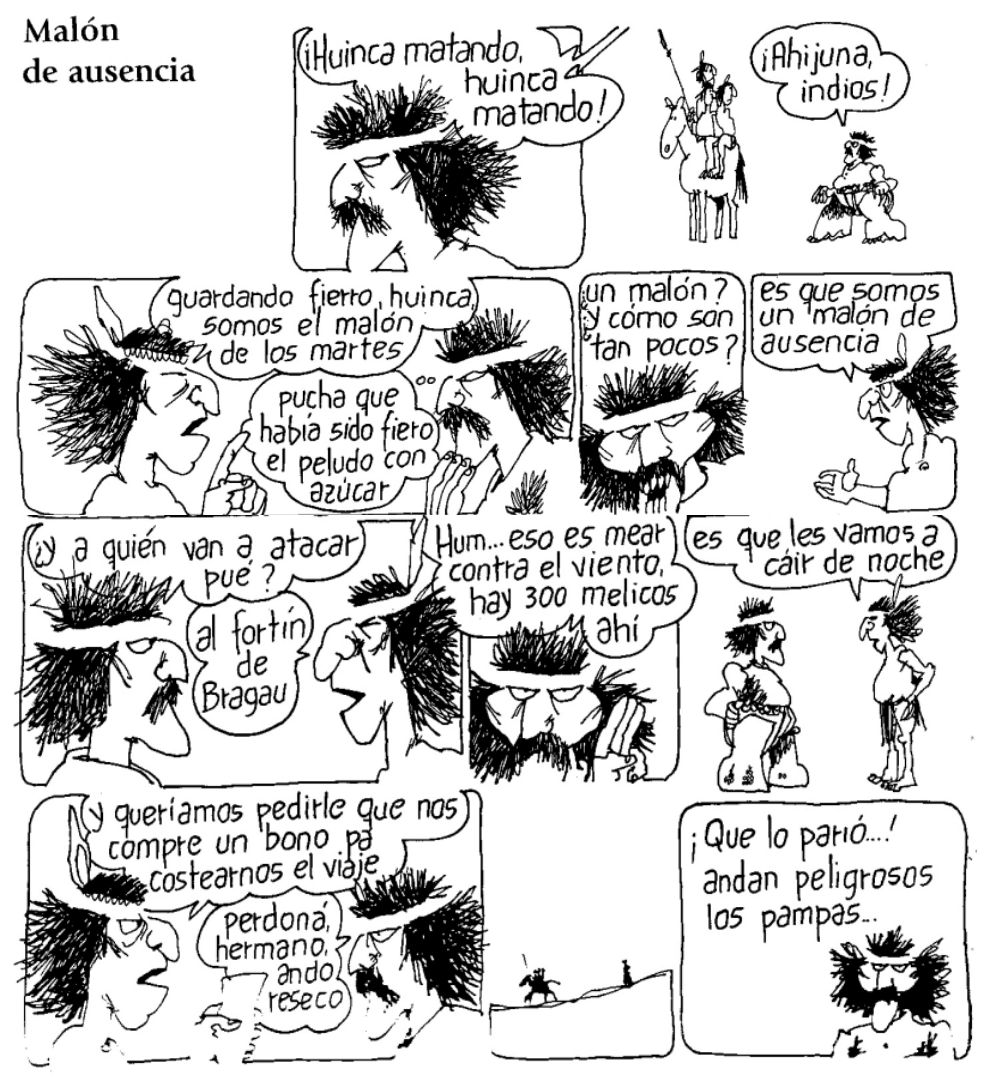

Fonte: FONTANARROSA, Roberto. 20 años con Inodoro Pereyra, p. 21.

\footnotetext{
${ }^{19}$ Homem branco, em língua indígena.
} 
Já no episódio "Hasta la hacienda baguala " Pereyra vai consultar ao feiticeiro pampa $^{20}$ Pechún-Corá para saber quando iria chover. O feiticeiro seria expert em provocar chuvas, um verdadeiro terror contra a escassez climática. Entretanto, Pechún-Corá diz para o gaucho que ele teria chegado fora de horário e a única coisa que ele teria para oferecer naquele momento era granizo. Pereyra sai decepcionado da tolderia ${ }^{21}$ do feiticeiro e conclui: "Grande bosta esse feiticeiro... Essa é boa, trabalhar agora sob regulamento".

Figura 13 - "Hasta la hacienda baguala".

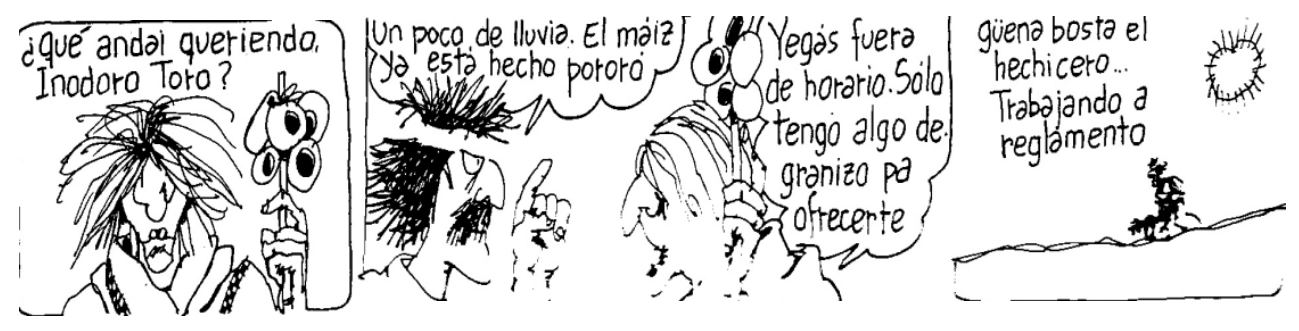

Fonte: Hortensia, $\mathrm{n}^{\circ}$ 50, fevereiro de 1974, p. 11.

Além dos índios pampas, outro grupo étnico mencionado nas historietas são os ranqueles. Aqui Fontanarrosa não poderia deixar de render tributo à narrativa epistolar Una excursión a los indios ranqueles, publicada dois anos antes da primeira parte do poema Martín Fierro por Lucio V. Mansilla. O livro trata da expedição político-militar do sobrinho de Rosas às tolderías ranquelinas e de sua internação em Tierra Adentro, lugar de índios bravos, gauchos renegados e tristes cativas.

No "Episodio salvaje y unitário" Pereyra encontra a um índio montado sobre um cavalo. $\mathrm{O}$ gaucho, então, pregunta: "Quem sois", ao que o indígena responde: "Sou ranquel e organizo excursões". Aqui se percebe claramente como funciona o trabalho desmistificador operado por Fontanarrosa, tendo em vista que a idéia do homem branco que faz uma excursão rumo à barbárie é desmistificada e invertida. Afinal, agora são os indios que organizam excursões, através de um complexo processo de mimese com a civilização, diferente da barbarização presente no relato de Mansilla. Enfim, se "os ranqueles estão na moda desde que Lucio Mansilla os

\footnotetext{
${ }^{20}$ Grupo indígena de origem mapuche habitante da região pampeana.

${ }^{21}$ Acampamento indígena.
} 
inventou" (IGLESIA, 2003, p. 548), foi com Inodoro Pereyra que eles adquiriram o protagonismo negado em outros momentos, inclusive de organizar sua própria excursão.

Figura 14 - "Episodio salvaje y unitario"

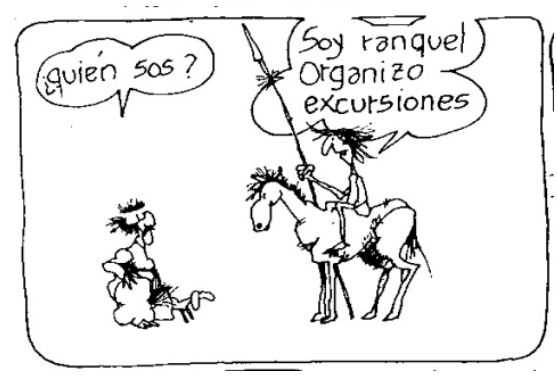

Fonte: Mengano, № 27, 1 a 14 de setembro de 1975.

Resumindo: nos quadrinhos de Inodoro Pereyra o Outro é fundamental para a constituição do relato. Este outro pode ser o indígena, o negro, o gringo, o turista ou o pueblero ${ }^{22}$, tal e qual ocorre na literatura gauchesca. No entanto, diferentemente desta, os papéis atribuídos ao gaucho e seus Outros aparecem trocados, o que gera a comicidade da narrativa. Se no Martín Fierro o Outro não tem valor absoluto, nas historietas de Inodoro Pereyra o que impera é o valor relativo de todos os personagens, do gaucho ao indígena, do homem da cidade ao turista perdido na imensidão do pampa. Nada é poupado nessa paródia estupenda da literatura gauchesca, e nem mesmo seria possível fazer com que Inodoro Pereyra tivesse um comportamento previsível para os seus leitores.

\section{Barbárie e civilização}

Nos quadrinhos de Inodoro Pereyra, a metáfora civilização e barbárie cunhada por Sarmiento é irreverentemente dessacralizada. Como exemplos, cito os episódios "Un mazorquero de navidad", "El vendaval no tiene riendas" e "La pampa dos senderos que se bifurcan".

Em "El vendaval no tiene riendas" ocorre um conflito entre o renegau e seu patrão, que paga muito caro pela afronta à "estirpe mocoví" de Inodoro Pereyra. A briga começa porque Pereyra teria degolado sem querer a um carneiro campeão. $O$ patrão, com os olhos crispados de cólera e segurando um açoite nas mãos, esbraveja: "Besta selvagem. Sarmiento tinha razão. Vou

\footnotetext{
${ }^{22}$ Referência ao homem da cidade.
} 
marcar o seu queixo". Porém, o gaucho responde com tranqüilidade: "Não faça com que eu me perca, patrão, que depois eu não me acho". Mais enfurecido ainda, Don Venancio Olavarría ameaça o renegau, desta vez com uma arma de fogo: "Gaucho desbocado, vais embora ou te queimarei as tripas". De repente, e tal e qual no episódio do seqüestro da Eulogia, Pereyra perde a paciência, vindo à tona toda a valentia de sua estirpe $\operatorname{mocovi}^{23}$ : "O último que gritou com Inodoro Pereyra está mudo agora. Levou a sua língua como escapulário. Aquele que falar mal do gaucho pagará com seu enterro. O senhor me manda embora, mas eu juro pela ossatura do meu flete que isso lhe custará caro... Muito caro". Após toda esta sequencia de bravura criolla, o episódio termina com a seguinte intervenção do narrador: "E caro custou ao patrão. Sessenta patacões de indenização e uma garrafa de ginebra ${ }^{24}$ por demitir Inodoro sem aviso prévio".

Figura 15 - "El vendaval no tiene riendas"

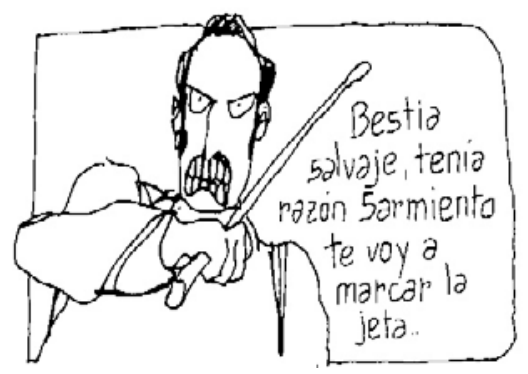

Fonte: Hortensia, $\mathrm{n}^{\circ}$ 29, março de 1973, p. 8

Em "La pampa de los senderos que se bifurcan" ocorre um encontro entre Don Inodoro e Jorge Luis Borges. A história parodia o conto borgiano "El Jardín de senderos que se bifurcan", de 1941, arquitetado a partir de uma trama policial. No episódio em questão, uma figura encapuzada pede que Inodoro a ajude a atravessar o pampa, pois temia ser atropelada pelo malón das seis horas. Durante a atravessia, os dois personagens começam a conversar e o desconhecido se apresenta: "Meu nome é Borges, mas pode me chamar de George". Em seguida ele diz: "Recordo que foi em Balvanera, numa noite que sinto saudades, que alguém deixou cair o nome de um tal Pereyra Inodoro". Neste trecho, parodia-se a poesia "Milonga de Jacinto Chiclana", escrita por Borges e reunida no livro Para las seis cuerdas. "Me acuerdo fue em Balvanera,/ En una noche lejana/ Que alguién dejó caer el nombre/ De un tal Jacinto Chiclana". Após escutar o trecho da

\footnotetext{
${ }^{23}$ Grupo indígena originário do que hoje seria o Norte Argentino.

${ }^{24}$ Genebra; bebida alcoólica muito comum no pampa.
} 
milonga, Inodoro comenta que o senhor encapazudo parecía ser "hombre léido". De maneira arrogante, Borges corrige o gaucho: “Léido' no. 'Leído' se dice. Palabra grave”. O clima da conversação fica tenso: “Facão' é uma palavra grave”, ameaça Inodoro. Finalmente, George arremata conclusivo: "É inútil, somos um símbolo: Civilização e barbárie". Mendieta, a voz do bom senso, tenta então convencer o renegau a "largar mão" daquele senhor pedante que os tratava com desprezo. Contudo, a gag final recai na paródia da canção "El corralero" ("Déjelo nomás pastar, no rechace mi consejo, que yo lo voy a enterrar, cuando se muera de viejo"), pronunciada por Inodoro como uma maneira de dizer que não necessariamente se deveria optar pela civilização ou pela barbárie. Quer dizer, ao sentenciar que se deveria "deixar o velho Borges passar", Inodoro mostra que a polarização sarmientina deveria ser abandonada, e uma nova história deveria ser escrita. "Ante a voz 'civilizada' as réplicas de Inodoro costumam ser o silêncio, a interpretação, a resposta desviada e os remates que misturam ingenuidade e ceticismo ante as atitudes dos representantes da 'civilização"' (MINELLI, 2010).

Figura 16 - "La pampa de los senderos que se bifurcan"

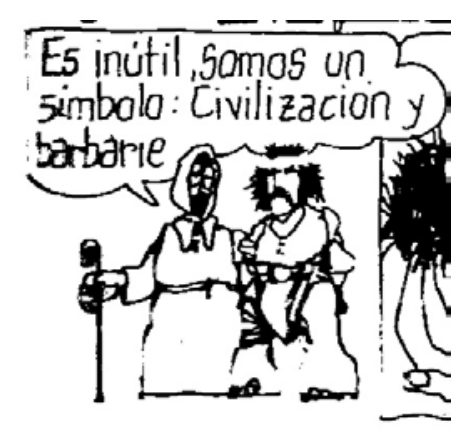

Fonte: Hortensia, $\mathbf{n}^{0}$ 38, julho de 1973, p. 18.

Em "El Mazorquero de Navidad" temos o diálogo nonsense entre Inodoro Pereyra e o Papai Noel, confundido com um mazorquero ${ }^{25}$. O diálogo desencontrado resulta na exclamação entusiasta do gaucho: “iViva la santa Federación. Mueran los salvajes unisex!”. O efeito cômico desta vinheta é resultado da burla de um dos topos mais contundentes na história argentina oitocentista, e tão forte na obra de inteletuais como Sarmiento e Hernández. A oposição unitários e federais, circunscrita por sua vez ao esquema civilização e barbárie, é simplesmente desmontada pela fala de don Inodoro, que parece estar pouco se importando se são "unitários" ou "unissex".

\footnotetext{
${ }^{25}$ Nome que se dava aos milicianos gauchos que integravam a Mazorca, aparato policial do rosismo.
} 
Figura 17 - "El Mazorquero de Navidad"

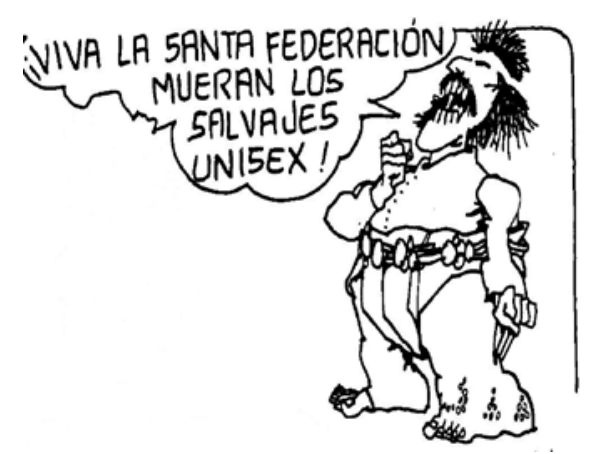

Fonte: Hortensia, $\mathrm{n}^{\circ}$ 46, dezembro de 1973, p. 18.

Enfim, através dessa distorção caricaturesca da "realidade", nota-se que a metáfora sarmientina é ressignificada nos quadrinhos criados por Fontanarrosa. Mas quem é o bárbaro e quem é o civilizado na epopéia criada pelo Negro? Notemos que a barbárie, substantivada no texto de Sarmiento, aparece nesta historieta de maneira altamente intercambiável, por vezes encarnada na figura dos índios ranqueles; em outros contextos, nos males decorrentes da vida civilizada; em outros momentos ainda, na própria violência do gaúcho Inodoro Pereyra. Podemos, assim, aventar a seguinte hipótese para explicar essa fluidez com que as balizas civilização e barbárie aparecem na obra de Fontanarrosa: talvez esta historieta seja a dessacralização risonha da própria metáfora sarmientina, que se baseia em uma "equação falsa, um jogo conceitual, uma frase de papel". Afinal, como já dizia José Martí, "não existe batalha entre civilização e barbarie, mas apenas entre a falsa erudição e a natureza”.

\section{A modo de conclusão}

No gênero gauchesco é recorrente a referência de um personagem ao outro, de modo que um não pode se furtar de render tributo ao modelo anterior. Assim, Hilario Ascasubi se declara continuador do legado de Hidalgo, e por sua vez é homenageado por Estanislao Del Campo 
através de "Anastasio el Pollo". Até mesmo José Hernández teria rendido tributo a uma obra anterior, Los tres gauchos orientales, do uruguaio Arturo Lussich.

\begin{abstract}
Ao tempo em que os autores da gauchesca se esforçam, quase unanimemente, por demonstrar que eles simplesmente copiam a vida, que nos seus textos somente se deve buscar a mera realidade transposta em palavras [...] e que nada mais distante deles que o intento de uma dicção literária e artística para a qual não se sentem capacitados [...], ao mesmo tempo se inscrevem todos [...] num movimento literário, declarando-se continuadores, aperfeiçoadores, meros discípulos e raras vezes discrepantes com os autores e obras do passado. Em poucas ocasiões se poderá comprovar de maneira tão evidente como a literatura nasce da literatura e por sua vez engendra literatura, nesta sucessão que vai de pais a filhos, de mestres a discípulos, de textos em textos (RAMA, 1977, p. xliv-xlv).
\end{abstract}

Com Inodoro Pereyra - exemplo de intertextualidade permanente, de crítica e de humor - a coisa não foi diferente, pois sua vida parece refletir tanto ao Martin Fierro de Hernández como a muitos outros gauchos anteriores. Porém, a grande novidade que traz esta HQ em relação ao gênero gauchesco do qual ela é tributária é que o modelo serve somente como uma matriz a partir da qual se inscreverão novos itinerários. $O$ jogo entre homenagem à gauchesca e negação da gauchesca é muito claro aqui.

Inclusive, pode-se considerar o episódio inicial que abre a série, "Cuando se dice adiós"26 como um rapto de originalidade, já que Fontanarrosa deliberadamente homenageia e rouba uma cena do Martín Fierro. Esta pretensão de inaugurar uma narrativa a partir do roubo de uma cena fundacional da história argentina pode estar relacionada à própria alcunha escolhida pelo quadrinista para o seu gaucho: el renegau. "Porque de guri renegava muito ao meu pai". Quer dizer, os quadrinhos de Pereyra dialogam o tempo todo com a tradição gauchesca da qual eles são tributários, a partir de um jogo que oscila entre a negação e a afirmação. Melhor dito, negam suas raízes através da afirmação das mesmas, burlando dessa paternidade forjada e artificial.

Nossa hipótese, portanto, é que os quadrinhos de Inodoro Pereyra podem ser lidos como outro olhar sobre a história da República Argentina, ressignificando e invertendo esquemas explicativos da história nacional. Canclini já havia dado a pista inicial de que Don Inodoro seria um ensaio de rediscussão da oposição entre unitários e federais (CANCLINI: 1997). A questão, contudo, é saber como esta HQ teria feito isso, e a partir de quais estratégias gráfico-textuais se passou de um discurso épico para outro paródico.

\footnotetext{
${ }^{26}$ Hortensia, ${ }^{\circ} 25$, dezembro de 1972, p. 21
} 
Como cópia de um contexto conhecido que se faz com humor, o relato de Inodoro Pereyra funciona como caixa de ressonância de uma série de discursos provenientes do vasto campo da gauchesca, entrecruzados com referências dos mass media e das indústrias culturais dos anos 1970. Isso significa dizer que o quadrinho está atravessado por uma ambigüidade estrutural: ora apresentado como modelo, ora como contra-modelo de determinado discurso sobre o gaucho argentino, a questão é que el renegau parece ter sua existência assegurada unicamente por meio desse mesmo discurso que pretende demolir.

De qualquer forma, acreditamos que o grande mérito deste quadrinho é rediscutir problemáticas fundadoras da história argentina através de um outro ponto de vista. A paródia funciona neste caso como um filtro através do qual se pode captar ângulos e perspectivas ainda não vistos: ao copiar um contexto já conhecido, pode-se modificá-lo, inserindo variáveis que geram a desfamiliarização e a ruptura do estereótipo. Logo, se o reconhecimento post mortem da figura do gaucho acabou cristalizando uma determinada versão sobre a história pátria, eis os quadrinhos de Inodoro Pereyra para trazer novamente o incômodo das narrativas de origem. Neste caso, a volta a um gesto fundador tem menos a pretensão de repetir um itinerário do que começar algo novo. Quer dizer, Inodoro Pereyra recupera o Martín Fierro com o objetivo de superá-lo. De forma inversa também se poderia postular que não é mais possível pensar no personagem hernandiano sem pensar-se no gaucho de Fontanarrosa.

Em suma, o mais importante que deve ser destacado é que através desta historieta é possível repensar importantes questões que marcaram a história argentina, e que foram responsáveis pela conformação de subjetividades e projetos identitários naquele país. Paródia estupenda da épica gauchesca, os quadrinhos de Inodoro Pereyra são um ótimo exemplo da desconstrução das fábulas de identidade cunhadas tanto na tradição literária argentina como no amplo espaço cultural da pós-modernidade. Quer dizer,

Há um século, os argentinos discutem se a política cultural deve optar pela civilização das metrópoles, rechaçando a barbárie do autóctone, ou por uma reivindicação enérgica do nacional-popular. Ao chegar à beira do século XXI, quando as indústrias culturais como as histórias em quadrinhos e as telenovelas nos fazem habitar um espaço internacional, frente à pergunta de se preferimos Sarmiento ou Rosas, é melhor nos aproximarmos de Inodoro Pereyra (CANCLINI: 1997, p. 341). 


\section{Referências}

\section{Fontes:}

Hortensia, Córdoba, 1972-1974

Mengano, Buenos Aires, 1974- 1976

\section{Bibliografia:}

ALTAMIRANO, Carlos e SARLO, Beatriz. Ensayos argentinos. De Sarmiento a la vanguardia. Buenos Aires: Ariel, 1997.

ANSOLABEHERE, Pablo. Martín Fierro: frontera y relato. In: LAERA, Alejandra. Fronteras escritas: límites, desvíos y pasajes en la literatura argentina. Rosario: Beatriz Viterbo, 2008.

BAKHTIN, Mikhail M. A cultura popular na Idade Média e no Renascimento: o contexto de François Rabelais. Brasília: UnB: Hucitec, 1987.

CANCLINI, Néstor García. Culturas híbridas estratégias para entrar e sair da modernidade. São Paulo: EDUSP, 1997.

DEL CARRIL, Bonifácio. El gaucho. Buenos Aires: Emecé, 1993.

FontANARROSA, Roberto. 20 años con Inodoro Pereyra. Buenos Aires: Ediciones de la Flor, 1998.

GARCIA, Fernando e OSTUNI, Hernán. "La historia de la historieta gauchesca" in Catálogo del Museo de Motivos Argentinos José Hernández, 1992.

GOCIOL, Judith e ROSEMBERG, Diego. La Historieta Argentina Una Historia. Buenos Aires: Ediciones de la Flor, 2000.

HERNÁNDEZ, José. El gaucho Martín Fierro. Disponível em: <http://www.literatura.org/Fierro/index.html>. Acesso em: 10 mar. 2010.

IGLESIA, Cristina. Mansilla, la aventura del relato. In: JITRIK, Noé. Historia crítica de la literatura argentina. Buenos Aires: Emecé, 2003.v. 2. 
MANDRINI, Raúl J.; ORTELLI, Sara. Una frontera permeable: Los indígenas pampeanos y el mundo rioplatense en el siglo XVIII. In: GUTIERREZ, H.; NAXARA, R. C.; LOPES, M. A. S. (Org.). Fronteiras: paisagens, personagens, identidades. São Paulo: Olho d'água, 2003.

MINELLI, María Alejandra. Reconfiguración de fronteras culturales (Argentina, XX y XXI). In: Escritores patagónicos. Disponível em:

$<$ http://escritorespatagonicos.8m.com/ensayos/minelli3.html>. Acesso em: 24 ago. 2010.

RAMA, Angel. Poesia Gauchesca. Caracas: Biblioteca Ayacucho, 1977.

ROMANO, Eduardo. Literatura/ Cine Argentinos sobre la (s) frontera (s). Buenos Aires: Catálogos Editora, 1991

SANGUILIANO, Héctor Sanyú (recopilación gráfica). MARTINEZ, Viviana e SFORZA (Investigación historica). 100 años de historieta en el mundo La historieta en la historia argentina. Buenos Aires: AIGLÉ Ediciones, s/ data.

SANTIS, Pablo. La historieta en la edad de la razón. Buenos Aires: Paidós, 1998.

SARMIENTO, Domingo Faustino. Facundo: civilización y barbarie. Buenos Aires: Agebe, 2004.

SASTURAIN, Juan. El domicilio de la aventura. Buenos Aires: Ediciones Colihue, 1995.

STEIMBERG, Oscar. Leyendo Historietas. Nueva Visión: Buenos Aires, 1977.

SVAMPA, Maristella. El dilema argentino: Civilización o Barbarie. De Sarmiento al Revisionismo Peronista. Buenos Aires: Ediciones el cielo por asalto: Imago Mundi, 1994.

Recebido em 30/02/2012

Aprovado em 30/05/2012 